\title{
House prices and bank credit in China: analysis of first- and second-tier cities
}

\begin{abstract}
Purpose: Housing prices in China have increased rapidly over the past decade. Motivated by the fact that the real estate market and bank credit scale are vastly different in Chinese cities, the purpose of this paper is to compare the impact of bank credit on house prices in first- and secondtier cities in China. Design/methodology/approach: In this study, a panel data method was used to investigate 19 first-tier cities and 30 second-tier cities between the period 2003 and 2018. Findings: The empirical analysis undertaken in this study found that bank credit was relevant to house prices but varied in different cities in which house prices in second-tier cities tended to be more affected by bank credit compared to those in first-tier cities. In contrast, population was found to be a dominant factor that influenced house prices in first-tier cities. Likewise, the factors, per capita and gross domestic product, were found to exert a significant influence on house prices in firstand second-tier cities. Practical implications: This paper provided numerous policies to control the price of housing in first- and second-tier cities. Originality/value: The housing prices, bank credit scale and population distribution are vastly different in different cities in China. This research considers these differences while examining the dominant factors that affect house prices in firstand second-tier cities in China.
\end{abstract}

Keyword: Bank credit; House price; Population; Per capita GDP; Cities; Panel method 